Age and the Rate of Foreign Language Learning 


\section{SECOND LANGUAGE ACQUISITION}

Series Editor: Professor David Singleton, Trinity College, Dublin, Ireland

This series brings together titles dealing with a variety of aspects of language acquisition and processing in situations where a language or languages other than the native language is involved. Second language is thus interpreted in its broadest possible sense. The volumes included in the series all offer in their different ways, on the one hand, exposition and discussion of empirical findings and, on the other, some degree of theoretical reflection. In this latter connection, no particular theoretical stance is privileged in the series; nor is any relevant perspective - sociolinguistic, psycholinguistic, neurolinguistic, etc. - deemed out of place. The intended readership of the series includes final-year undergraduates working on second language acquisition projects, postgraduate students involved in second language acquisition research, and researchers and teachers in general whose interests include a second language acquisition component.

\section{Other Books in the Series}

Effects of Second Language on the First Vivian Cook (ed.)

Age and the Acquisition of English as a Foreign Language María del Pilar García Mayo and Maria Luisa García Lecumberri (eds)

Fossilization in Adult Second Language Acquisition ZhaoHong Han

Silence in Second Language Learning: A Psychoanalytic Reading Colette A. Granger

Age, Accent and Experience in Second Language Acquisition Alene Moyer

Studying Speaking to Inform Second Language Learning Diana Boxer and Andrew D. Cohen (eds)

Language Acquisition: The Age Factor (2nd edn) David Singleton and Lisa Ryan

Focus on French as a Foreign Language: Multidisciplinary Approaches Jean-Marc Dewaele (ed.)

Second Language Writing Systems Vivian Cook and Benedetta Bassetti (eds)

Third Language Learners: Pragmatic Production and Awareness Maria Pilar Safont Jordà

Artificial Intelligence in Second Language Learning: Raising Error Awareness Marina Dodigovic

Studies of Fossilization in Second Language Acquisition ZhaoHong Han and Terence Odlin (eds)

Language Learners in Study Abroad Contexts Margaret A. DuFon and Eton Churchill (eds)

Early Trilingualism: A Focus on Questions Julia D. Barnes

Cross-linguistic Influences in the Second Language Lexicon Janusz Arabski (ed.)

Motivation, Language Attitudes and Globalisation: A Hungarian Perspective Zoltán Dörnyei, Kata Csizér and Nóra Németh

For more details of these or any other of our publications, please contact: Multilingual Matters, Frankfurt Lodge, Clevedon Hall, Victoria Road, Clevedon, BS21 7HH, England http://www.multilingual-matters.com 


\section{Age and the Rate of Foreign Language Learning}

Edited by

Carmen Muñoz 
Library of Congress Cataloging in Publication Data

Age and the Rate of Foreign Language Learning / Edited by Carmen Muñoz.

Second Language Acquisition: 19)

1. Language acquisition-Age factors. 2. Language and languages-Study and teaching.

I. Muñoz, Carmen. II. Second Language Acquisition (Clevedon, England): 19.

P118.65.A373 2006

$418-$ dc22 2006003667

British Library Cataloguing in Publication Data

A catalogue entry for this book is available from the British Library.

ISBN 1-85359-892-5/ EAN 978-1-85359-892-0 (hbk)

ISBN 1-85359-891-7/ EAN 978-1-85359-891-3 (pbk)

\section{Multilingual Matters Ltd}

UK: Frankfurt Lodge, Clevedon Hall, Victoria Road, Clevedon BS21 7HH.

USA: UTP, 2250 Military Road, Tonawanda, NY 14150, USA.

Canada: UTP, 5201 Dufferin Street, North York, Ontario M3H 5T8, Canada.

Copyright (c) 2006 Carmen Muñoz and the authors of individual chapters.

All rights reserved. No part of this work may be reproduced in any form or by any means without permission in writing from the publisher.

Typeset by Saxon Graphics.

Printed and bound in Great Britain by the Cromwell Press Ltd. 